\title{
Evaluation of the Antimicrobial Activity and Cytotoxicity of Different Components of Natural Origin Present in Essential Oils
}

\author{
Sara García-Salinas ${ }^{1,+}$, Hellen Elizondo-Castillo ${ }^{1,+}$, Manuel Arruebo ${ }^{1,2,3}$, \\ Gracia Mendoza $1,3, *$ (iD) and Silvia Irusta $1,2,3, *$ (D) \\ 1 Department of Chemical and Environmental Engineering, Aragon Institute of Nanoscience (INA), \\ University of Zaragoza, Campus Río Ebro-Edificio I+D, C/Poeta Mariano Esquillor S/N, \\ 50018 Zaragoza, Spain; saragarciasalinas@gmail.com (S.G.-S.); helizondo02@gmail.com (H.E.-C.); \\ arruebom@unizar.es (M.A.) \\ 2 Networking Research Center on Bioengineering, Biomaterials and Nanomedicine, CIBER-BBN, \\ 28029 Madrid, Spain \\ 3 Aragon Health Research Institute (IIS Aragón), 50009 Zaragoza, Spain \\ * Correspondence: gmmenc@unizar.es (G.M.); sirusta@unizar.es (S.I.); Tel.: +34-876-555-437 (S.I.) \\ + These authors contributed equally to this work.
}

Received: 23 May 2018; Accepted: 5 June 2018; Published: 8 June 2018

\begin{abstract}
Even though essential oils (EOs) have been used for therapeutic purposes, there is now a renewed interest in the antimicrobial properties of phytochemicals and EOs in particular. Their demonstrated low levels of induction of antimicrobial resistance make them interesting for bactericidal applications, though their complex composition makes it necessary to focus on the study of their main components to identify the most effective ones. Herein, the evaluation of the antimicrobial action of different molecules present in EOs against planktonic and biofilm-forming Gram-positive (Staphylococcus aureus) and Gram-negative (Escherichia coli) bacteria was assessed. The bactericidal mechanisms of the different molecules, as well as their cytocompatibility, were also studied. Carvacrol, cinnamaldehyde, and thymol exhibit the highest in vitro antimicrobial activities against $E$. coli and $S$. aureus, with membrane disruption the bactericidal mechanism identified. The addition of those compounds $(\geq 0.5 \mathrm{mg} / \mathrm{mL})$ hampers $S$. aureus biofilm formation and partially eliminates preformed biofilms. The subcytotoxic values of the tested EO molecules $(0.015-0.090 \mathrm{mg} / \mathrm{mL})$ are lower than the minimum inhibitory and bactericidal concentrations obtained for bacteria $(0.2-0.5 \mathrm{mg} / \mathrm{mL})$ but are higher than that obtained for chlorhexidine $(0.004 \mathrm{mg} / \mathrm{mL})$, indicating the reduced cytotoxicity of EOs. Therefore, carvacrol, cinnamaldehyde, and thymol are molecules contained in EOs that could be used against E. coli- and S. aureus-mediated infections without a potential induction of bactericidal resistance and with lower cell toxicity than the conventional widely used chlorhexidine.
\end{abstract}

Keywords: antimicrobial; essential oils; monoterpenoids; cytotoxicity; wound dressings

\section{Introduction}

Since the discovery of penicillin, the use of antibiotics, originally developed for human healthcare, has been extended to animal therapeutics and agriculture [1]. The use and misuse of antibiotics has led to the emergence of antibiotic resistance in human and animal pathogens, which is recognized as a serious and global concern because resistance in common bacteria has reached alarming levels in all parts of the world [2]. The continued evolution of antimicrobial resistance (AMR) in hospitals is a growing concern because of its potential to endanger the future of antimicrobial drug therapy [3]. 
Even the new generation of antibiotics is becoming virtually ineffective, and it is predicted that AMR will cause more deaths than cancer-associated diseases by the middle of the century [4]. The discovery of strains resistant to all antibiotics available in the clinic has also made an impact on society in general [5]. Sub-inhibitory antibiotic doses help stepwise selection of resistance, and the resulting resistant clones like methicillin-resistant Staphylococcus aureus, Escherichia coli, and Klebsiella are rapidly disseminated. The overall burden of staphylococcal disease caused by methicillin-resistant $S$. aureus (MRSA) strains is increasing in many countries in both healthcare and community settings [6]. Multiple antimicrobial resistance determinants have been found in E. coli on the same plasmid, further facilitating their propagation and co-selection. For instance, the multidrug resistance plasmid IncA/C found in E. coli, often encodes for resistance to common antimicrobial agents such as tetracycline, chloramphenicol/florfenicol, streptomycin/spectinomycin, sulfonamides, and extended spectrum $\beta$-lactamases, and its spread to pathogenic bacteria may limit antibacterial means to fight infections caused by these bacteria [3].

Because of the emergence of AMR, the Center for Disease Control (CDC) has endorsed the need for the development of new antibiotics. However, the elaboration of new antibiotics is expensive and time-consuming. Meanwhile, the genetic plasticity in pathogens results in the development of resistance at a rapid rate [7]. Therefore, there is a crucial need for research of new substances with the potential to combat resistant strains to minimize their selection. In 2011, academics and industry collaborated on a priority list for approaches to resolve the "antimicrobial-resistance crisis." Amongst the potential strategies suggested, the development of alternatives to antibiotics were proposed [8]. Compounds from natural sources such as animals, plants, and microorganisms have been highlighted as renewed potential antimicrobial alternatives [9]. Famous seafarers (e.g., Marco Polo) established routes for specie trade, and different compounds of natural origin present in species are still being used today to prevent foodborne pathogens showing low levels of antimicrobial resistance [10]. Antibiotics by definition have a natural origin (i.e., penicillin is derived from Penicillium fungi), and antimicrobials of synthetic origin used to fight against infection are considered as drugs (i.e., isoniazid). However, there are several antibiotics that have multiple mechanisms of action. In this regard, essential oils (EO) are oily aromatic substances extracted from plants with antibacterial, antifungal, insecticidal, and antiviral properties. EOs have been distilled for more than 2000 years, and there is now renewed interest in the antimicrobial properties of phytochemicals and EOs in particular. The demonstrated low levels of induction of antimicrobial resistance toward EOs could be related to the fact that these substances do not attack a single specific target but have multiple modes of antibacterial action [1]. Antibiotics, and antiseptics like chlorhexidine, have been shown to be able to generate resistance in Staphylococcus [11] by mechanisms (mutations in qacA/B gene) that may be common to other microorganisms. However, EO-based compounds are reported as unable to generate antimicrobial resistances in studies involving Gram negative and Gram positive microorganisms subsequently treated with clove, thyme, cinnamon, and oregano oils [12-15].

EOs are complex blends of a variety of molecules such as terpenoids, phenol-derived aromatic components, and aliphatic components. Their compositions depend on factors such as seasonal variation, climate, plant organ, age, subspecies, and even the oil extraction method. Consequently, the extracted product can fluctuate in quality, quantity, and composition [16]. Generally, EOs contain about 20-60 components, up to more than 100 single substances, at quite different concentrations; two or three are major components at fairly high concentrations (20-70\%) compared to other components that are present only in trace amounts. Because of this, in order to have a systematic evaluation of EOs' antibacterial activity, it is necessary to focus on the study of their main components.

Different extracted components from EOs such as carvacrol, thymol, eugenol, perillaldehyde, and cinnamaldehyde have been reported as antibacterial agents [17]. However, the reported values for their minimum inhibitory (MICs) and bactericidal (MBCs) concentrations are extremely divergent. For example, the MIC of carvacrol toward S. aureus found in the literature ranges from approximately $0.15 \mathrm{mg} / \mathrm{mL}$ [18] to $15 \mathrm{mg} / \mathrm{mL}$ [19]. In some cases, the different MICs reported could be attributed 
to the bacteria strain used. Wang et al. [20] reported an MIC value for carvacrol of $0.31 \mathrm{mg} / \mathrm{mL}$ for S. aureus ATCC 43300, while using S. aureus ATCC 6538, Silva da Luz et al. [21] reported a MIC of $2.5 \mu \mathrm{L} / \mathrm{mL}$ (approximately $2.45 \mathrm{mg} / \mathrm{mL}$ ) for the same component. Even for the same bacteria strain (ATCC 6538), MIC values for carvacrol of $0.4 \mathrm{mg} / \mathrm{mL}$ [22] and $0.015 \% v / v$ (approximately $0.147 \mathrm{mg} / \mathrm{mL}$ ) [18] can be found in the literature.

Beside the well-documented antibacterial action of EO components, there is some evidence corroborating the enhancement in the antimicrobial action of EO components used in combination with other antimicrobial agents, both synthetic and natural [23]. Thymol and carvacrol were found to have additive antibacterial effect against S. aureus, E. coli, Salmonella, and Bacillus cereus. Ye et al. [24] tested the synergy between cinnamaldehyde and carvacrol in S. aureus and E. coli among other bacteria and concluded that cinnamaldehyde and carvacrol exhibit high antibacterial activities and have synergistic antimicrobial action against these bacteria. Thymol and carvacrol were found to give an additive effect when tested against $S$. aureus and Pseudomonas aeruginosa [25]. Thymol combined with carvacrol had a synergistic effect against Salmonella typhimurium [26].

One interesting application of EO components with antimicrobial activity would be their incorporation into wound dressings since they can prevent or treat wound-associated infections and aid tissue regeneration [27]. Bacterial components have been highlighted as harmful factors during wound healing due to their interference with cell-matrix interactions and due a reduced inflammatory response they produce. In this regard, S. aureus colonize from 30\% to 50\% of healthy adults and is able to rapidly infect skin lesions with a consequential inflammatory process [28]. E. coli is also among the main bacterial species that commonly colonize skin wounds, and from this initial colonization, severe problems can occur such as topical infections or even sepsis [29]. Within the clinical settings, biofilm formation is a pressing challenge that leads to chronic infections. Prevention of biofilm formation is considered preferable to its removal, since the latter is a very difficult and demanding task, which can cause recontamination problems due to the uncontrolled release of bacterial cells and toxins after their disruption. One of the outstanding antimicrobial properties of many EOs is that they can also be effective even against microbial biofilms [30].

The aim of this work was to shed light on the evaluation of the bactericidal activity and mechanisms of action of EO-present molecules against S. aureus and E. coli in planktonic growth. The antibiofilm efficiency and the possibility of synergy between carvacrol (CRV), cinnamaldehyde (CIN) and thymol (THY) were also analyzed. The potential toxicity of those components was also investigated in different cell types, including human dermal fibroblasts, keratinocytes, and macrophages. The main goal of this work is to deepen our understanding of the effects and mechanisms of these purified molecules on bacteria, avoiding the intrinsic variability of their extraction from plants, and focusing on their own ability to hamper bacteria growth and colonization.

\section{Results}

\subsection{Bactericidal Activity against Planktonic Bacteria}

\subsubsection{MIC and MBC Values}

The antibacterial effect of several components present in different EOs reported as bactericidal, such as carvacrol [31], thymol [32], cinnamaldehyde [33], eugenol [34], $\beta$-caryophyllene [35], and rosmarinic acid [36], were studied. Squalene, a well-known natural antioxidant [37], was also included in the study for comparison. Table 1 and Figure S1 show the MIC and MBC results of the components against E. coli and S. aureus. The most active compounds were THY, CRV, CIN, and eugenol, showing significant differences against the control sample. 
Table 1. Chemical structure and minimal inhibitory concentration (MIC) and minimal bactericidal concentration $(\mathrm{MBC})$ values of different essential oil contained compounds. Average of 12 replicas each compound.

\begin{tabular}{|c|c|c|c|c|c|}
\hline \multirow{2}{*}{ Active Compound } & \multirow{2}{*}{ Structure } & \multicolumn{2}{|c|}{ MIC (mg/mL) } & \multicolumn{2}{|c|}{$\mathrm{MBC}(\mathrm{mg} / \mathrm{mL})$} \\
\hline & & E. coli & S. aureus & E. coli & S. aureus \\
\hline Carvacrol & & 0.2 & 0.2 & 0.4 & 0.3 \\
\hline Cinnamaldehyde & & 0.2 & 0.4 & 0.3 & 0.5 \\
\hline Thymol & & 0.2 & 0.2 & 0.3 & 0.3 \\
\hline Eugenol & & 0.4 & 1.3 & 0.5 & 1.5 \\
\hline$\beta$-caryophyllene & & $>4.0$ & $>4.0$ & $>4.0$ & $>4.0$ \\
\hline Rosmarinic acid & & $>4.0$ & 2.5 & $>4.0$ & 4.0 \\
\hline Squalene & & $>4.0$ & $>4.0$ & $>4.0$ & $>4.0$ \\
\hline
\end{tabular}

\subsubsection{Bactericidal Mechanism}

E. coli and S. aureus exposed during $24 \mathrm{~h}$ to CRV, CIN, and THY at MIC and MBC concentrations were morphologically examined by scanning electron microscopy (SEM) (Figure 1). The morphology and microstructure of $S$. aureus before being exposed to any compound can be observed in Figure 1A, having a normal and spherical shape and a well-preserved cell membrane. However, after exposition to CRV, CIN and THY at MICs for $24 \mathrm{~h}$ (Figure 1B-G), the morphology of S. aureus was distorted. Part of the cell peptidoglycan structure appeared depressed, indicating an initial damage. S. aureus exposed to $\mathrm{MBC}$ concentrations during $24 \mathrm{~h}$ became deformed and wrinkled, indicating that the intracellular content had leaked out. There was a reduced number of bacteria in the samples, and it was hard to find the ones exposed to CIN, probably due to the severe damage to the bacterial peptidoglycan layer and cell membrane and subsequently cell death and detachment from the filter holder. The reduction in cell size, length, and diameter observed for S. aureus in response to the active compound could be reasonably attributed to the leakage of cytosolic fluids outside the cells. E. coli untreated cells were rod shaped, regular, and with intact morphology (Figure 2A) in contrast to MIC-treated cells (Figure 2B-G). SEM images showed morphological alterations and lyses of the outer membrane integrity in cells exposed at MICs. At MBC, a complete lysis or seriously damaged cells were observed. 


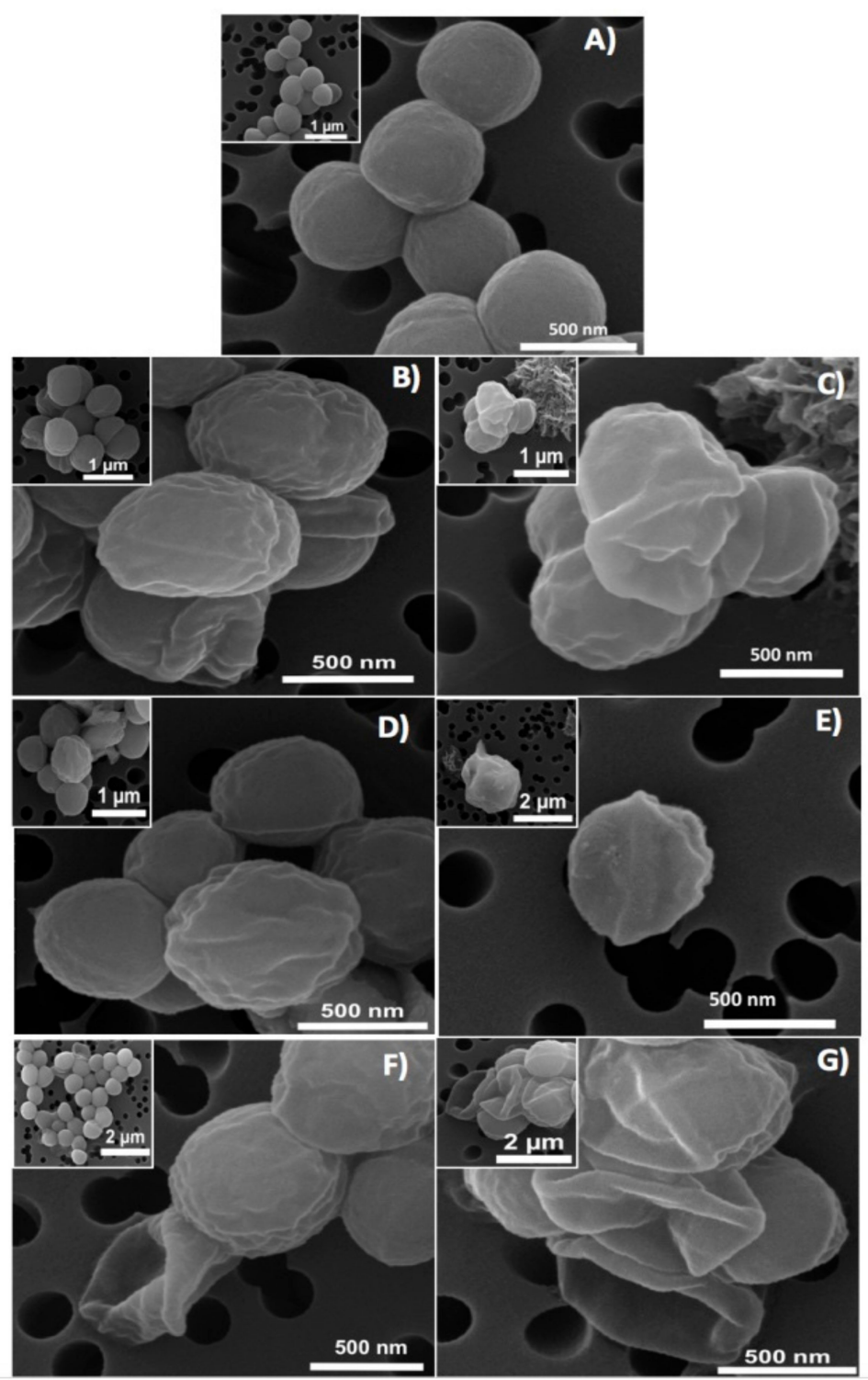

Figure 1. Scanning electron microscopy (SEM) images of S. aureus (A) untreated (control sample); treated bacteria during $24 \mathrm{~h}$ with MIC of (B) carvacrol; (D) cinnamaldheyde; (F) thymol; treated bacteria during $24 \mathrm{~h}$ with MBC of (C) carvacrol; (E) cinnamaldheyde; (G) thymol. 

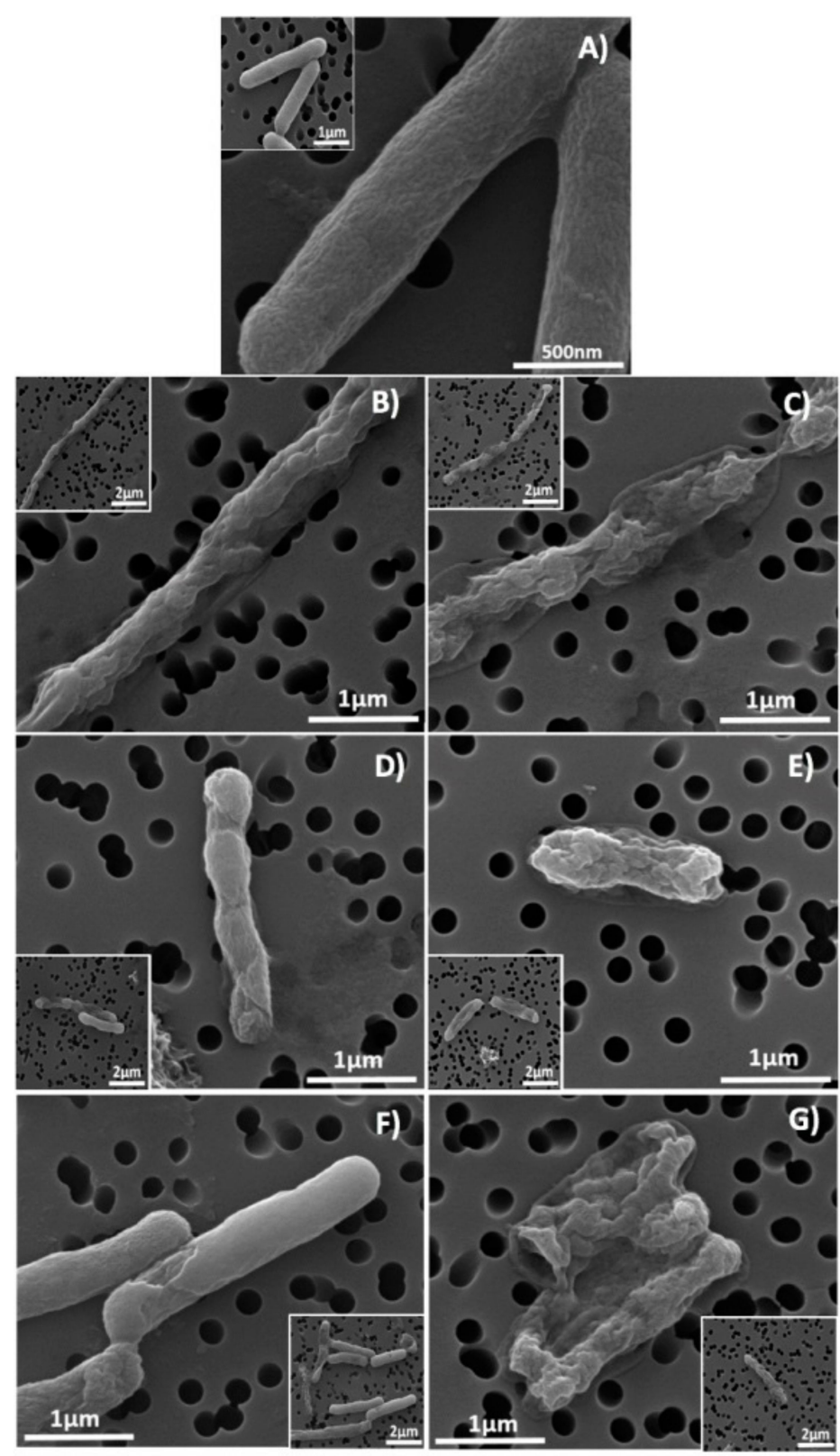

Figure 2. SEM images of E. coli (A) untreated (control sample); treated bacteria during $24 \mathrm{~h}$ with MIC of

(B) carvacrol; (D) cinnamaldheyde; (F) thymol; treated bacteria during $24 \mathrm{~h}$ with MBC of (C) carvacrol;

(E) cinnamaldheyde; (G) thymol.

In order to confirm the bactericidal mechanism of the active compounds present in EOs, flow cytometry and confocal microscopy studies were developed. Flow cytometry histograms (Figure S2) displayed peaks in the range of the negative control (damaged membrane caused by chlorhexidine [38]) when $S$. aureus and E. coli were treated with the tested compounds at MBC, which is consistent with cell membrane disruption as previously reported [39]. Only CIN-treated cells show peaks slightly displaced toward the positive control (undamaged membrane) for both microorganisms, suggesting that the involvement of cell membrane disruption in bacteria death was not as clear as the SEM images showed. However, confocal microscopy images (Figure 3 and Figure S3) clearly confirmed membrane damage exerted by the compounds tested when bacteria were incubated with the MICs of the molecules, showing red staining related to membrane integrity compromise. Furthermore, in the case of E. coli, the damaged membrane areas can be clearly distinguished (Figure 3D-F). All these 
results point out to the bacteria membrane disruption as the bactericidal mechanism exerted by the compounds present in the EOs.
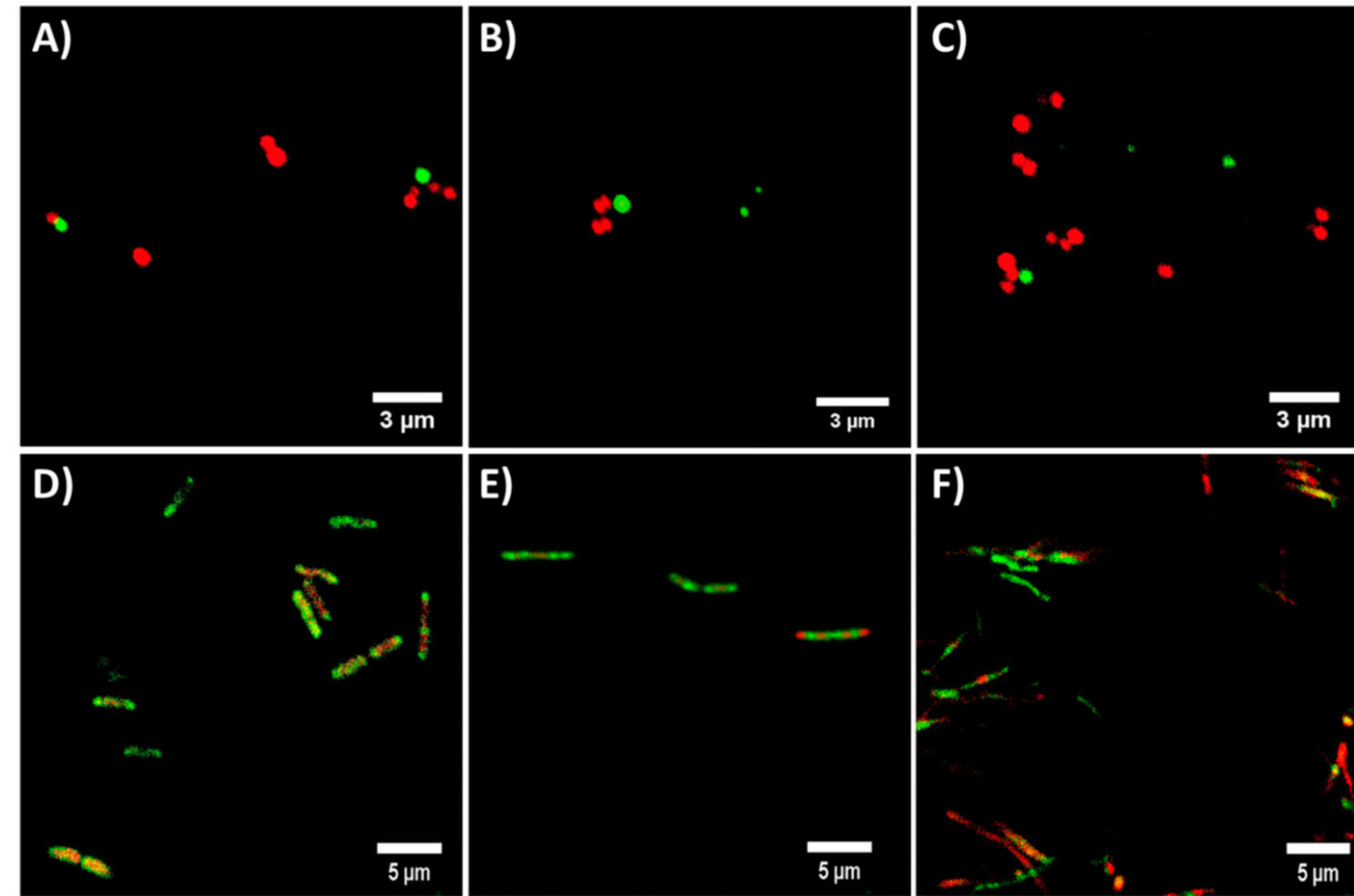

Figure 3. Confocal microscopy images of S. aureus (A-C) and E. coli (D-F) treated with the MIC of carvacrol (A,D), cinnamaldheyde (B,E) and thymol (C,F), stained with the Live/Dead ${ }^{\circledR}$ BacLight $^{\mathrm{TM}}$ bacterial viability kit. Red staining displays membrane damage.

\subsubsection{Synergism}

Synergistic interactions between EO active compounds may increase their efficacy as antibacterial agents. In our studies, the Fractional Inhibitory Concentration Index (FICI) values obtained against S. aureus (Table 2; Figure S4) indicate that only the CRV-THY combination has an additive effect, while CIN has no interaction with the other compounds tested. These results may be related to their chemical structure as CRV and THY have almost the same molecular structure (Table 1). It is worth noting that all the FICI values are smaller than 4.0 indicating that there is no antagonism between the tested active compounds.

Table 2. Fractional Inhibitory Concentration (FIC) and Fractional Inhibitory Concentration Index (FICI) values for active compounds combination.

\begin{tabular}{|c|c|c|c|c|c|c|c|c|c|c|c|}
\hline \multicolumn{4}{|c|}{ Carvacrol-Cinnamaldehyde } & \multicolumn{4}{|c|}{ Carvacrol-Thymol } & \multicolumn{4}{|c|}{ Thymol-Cinnamaldehyde } \\
\hline $\mathrm{FIC}_{\mathrm{CRV}}$ & $\mathrm{FIC}_{\mathrm{CIN}}$ & FICI & & $\mathrm{FIC}_{\mathrm{CRV}}$ & $\mathrm{FIC}_{\mathrm{THY}}$ & FICI & & $\mathrm{FIC}_{\mathrm{THY}}$ & FIC $_{\mathrm{CIN}}$ & FICI & \\
\hline 0.7 & 1.0 & 1.7 & $\mathrm{NI}^{1}$ & 0.4 & 0.5 & 0.9 & $\mathrm{ADD}^{2}$ & 0.8 & 0.4 & 1.2 & $\mathrm{NI}^{1}$ \\
\hline
\end{tabular}

\subsection{Antibiofilm Activity}

S. aureus biofilm formation was observed by calcofluor white staining and by SEM analysis after incubation for $16 \mathrm{~h}$ (Figure 4A,B, respectively). The quantification (colony forming units per milliliter $=\mathrm{CFU} / \mathrm{mL}$ ) carried out after incubation of the formed biofilm (Figure $5 \mathrm{~A}$ ) with the antimicrobial 
compounds has shown a statistically significant decrease in bacteria growth compared to the untreated biofilms. At $0.5 \mathrm{mg} / \mathrm{mL}$ of EO-contained molecules, preformed biofilms showed a reduction in bacteria growth around 2 logs when biofilm was treated with CIN, while CRV and THY exerted a superior decrease (3 logs). The highest tested concentration $(1 \mathrm{mg} / \mathrm{mL})$ showed a reduction in CFU $/ \mathrm{mL}$ higher than 5 logs. As expected, concentrations of the active molecules higher than MIC and even MBC values obtained for planktonic bacteria are needed for biofilm elimination.

The addition of these compounds to the bacteria suspension before biofilm formation hindered this process since there was a significant decrease in the posterior bacterial growth (4 logs for CIN) (Figure 5B). THY and CRV produced even higher reductions of about 5 and 6 logs, respectively. Again, the concentrations needed to retard biofilm growth and development were higher than the MIC values retrieved for planktonic bacteria (Table 1).

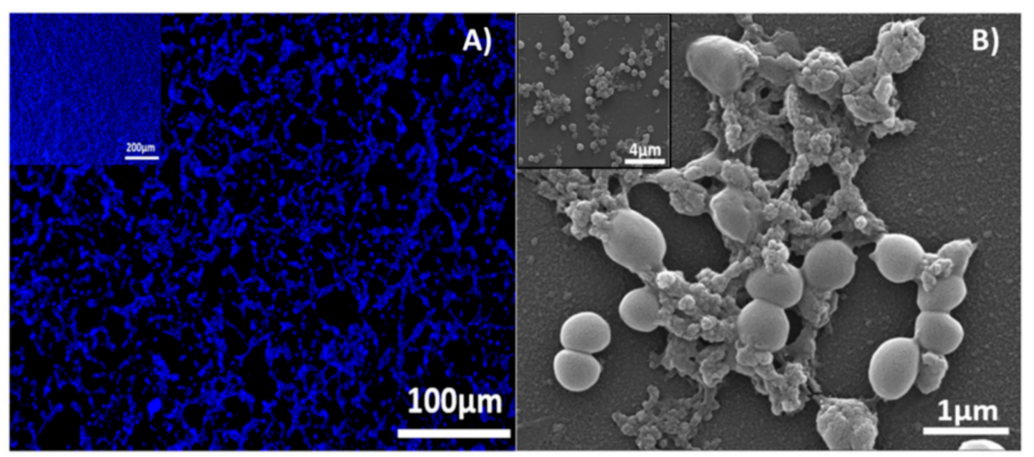

Figure 4. Calcofluor staining (A) and SEM images of S. aureus biofilm formed after $16 \mathrm{~h}$ (B).

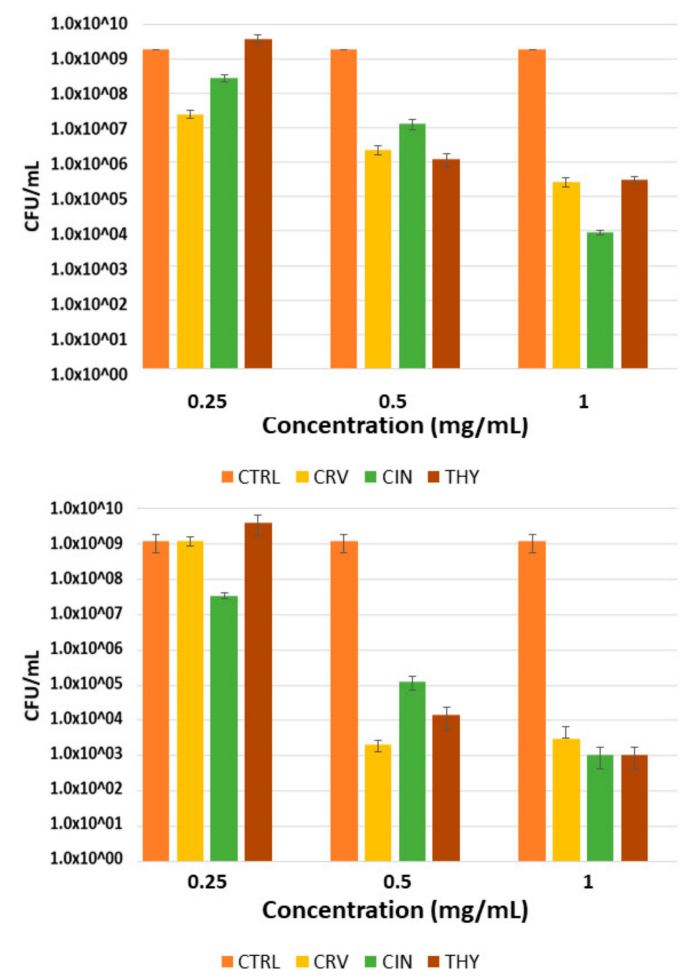

Figure 5. Effect of EOs components at different concentrations on S. aureus biofilm: elimination of preformed biofilm (A) and inhibition of biofilm formation (B). CTRL = Control sample (not treated biofilm), CRV = biofilm treated with Carvacrol, CIN = biofilm treated with cinnamaldehyde, THY = biofilm treated with thymol. 


\subsection{Cytotoxicity}

Cytocompatibility and not cytotoxicity is required for a wound-healing product since it would be in contact with the infected wound tissue and its neighboring eukaryotic cells. The cytotoxicity activities of these antimicrobial compounds were investigated using fibroblasts, macrophages, and keratinocytes cell lines (Figure 6). Inflammatory cells such as macrophages are generated during wound healing [40], whereas keratinocytes and fibroblasts are part of the epidermis and dermis, respectively. Due to the insolubility of those compounds in aqueous media, those were dispersed using Tween ${ }^{\circledR} 80$ (Sigma-Aldrich, St. Louis, MO, USA) as described in the materials and methods section. Hence, the cytotoxicity of the free compounds would be reduced in absence of Tween ${ }^{\circledR} 80$ due to their nonpolar character.
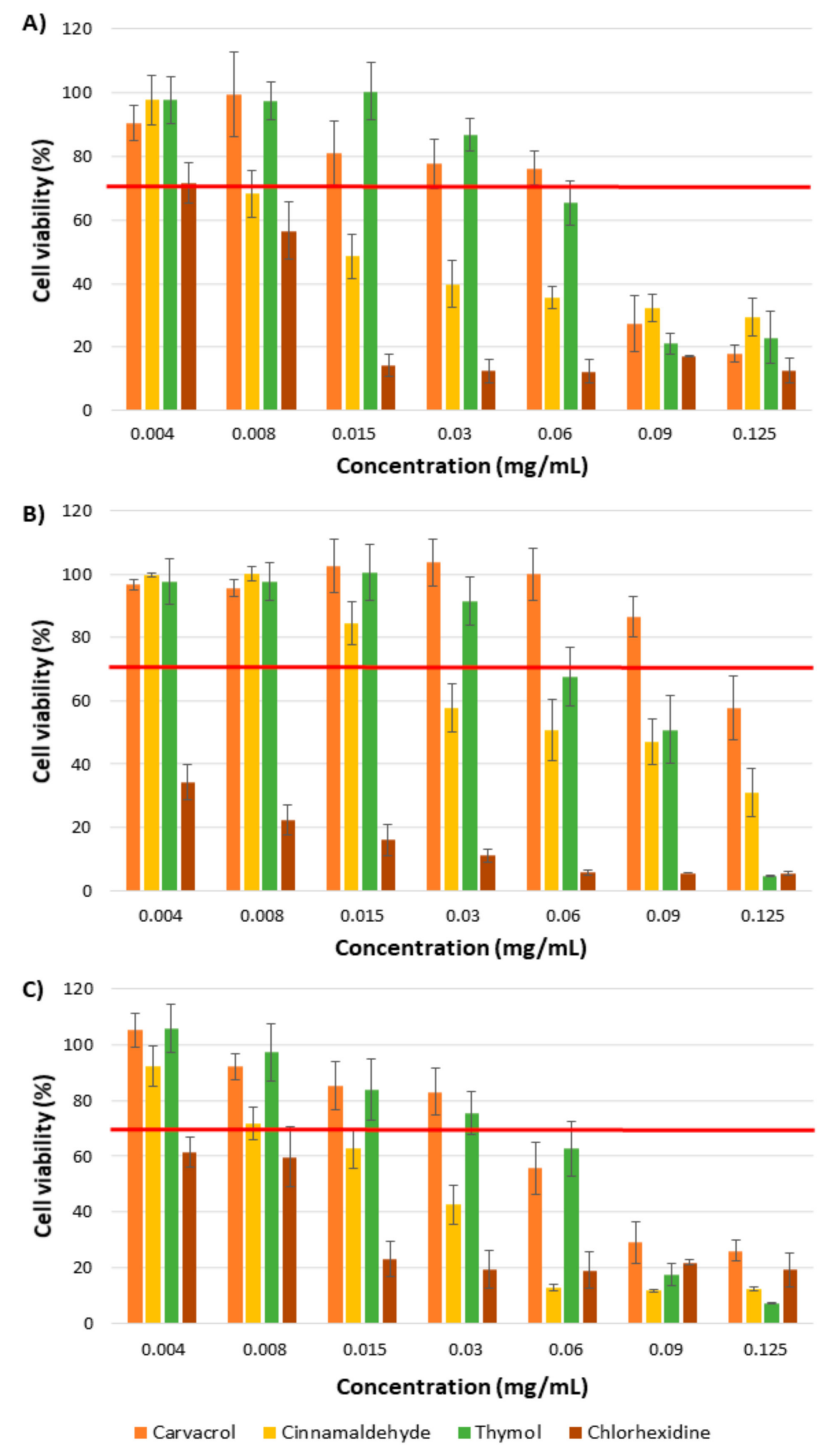

Figure 6. Cell viability after treatment with carvacrol, cinnamaldehyde, thymol and chlorhexidine for $24 \mathrm{~h}$ on human dermal fibroblasts (A); macrophages (B); keratinocytes (C). Control sample (untreated cells) $=100 \%$ viability.

CIN was the most cytotoxic chemical of the tested molecules; a dose of $0.030 \mathrm{mg} / \mathrm{mL}$ of this compound was enough to reduce the viability of keratinocytes and macrophages below $70 \%$ (lowest value established by the ISO 10993-5 [41] to consider a material as non-cytotoxic), and $0.015 \mathrm{mg} / \mathrm{mL}$ affects the fibroblasts viability (Figure 6). THY and CRV can be considered toxic to fibroblasts at concentrations equal 
or higher than $0.090 \mathrm{mg} / \mathrm{mL}$, and the calculated subcytotoxic doses for keratinocytes were 0.060 and $0.030 \mathrm{mg} / \mathrm{mL}$, respectively. There is also a difference between the effect of THY and CRV on macrophages, since subcytotoxic concentrations were 0.060 and $0.090 \mathrm{mg} / \mathrm{mL}$, respectively.

Chlorhexidine, a typical disinfectant and antiseptic drug used in skin disinfection, was tested for comparison. For the studied concentrations $(0.004-0.125 \mathrm{mg} / \mathrm{mL})$, chlorhexidine reduces the viability of the three cellular types to $70 \%$ or below. Only fibroblasts show viability higher than $70 \%$ in presence of chlorohexidine at $0.004 \mathrm{mg} / \mathrm{mL}$. For keratinocytes and macrophages, the subcytotoxic concentration was lower than $0.004 \mathrm{mg} / \mathrm{mL}$.

These subcytotoxic values of the tested compounds were lower than the MICs and MBCs retrieved for bacteria but higher than those obtained with chlorhexidine. In order to reduce bacterial burden in wounds, topical antiseptic agents, among them chlorohexidine gluconate, are usually applied as 2 and $4 v / v \%$ topical solutions, concentrations five orders of magnitude higher than the subcytotoxic doses. Therefore, in our study, the presence of antibacterial compounds of natural origin in a wound dressing material at MBC concentrations would be only three orders of magnitude higher than the subcytotoxic dose in the worst case scenario demonstrating that those natural origin compounds are less harmful against eukaryotic cells than conventional antiseptics.

\section{Discussion}

Microorganism resistance to antibiotics and antiseptics has become a serious problem in the treatment of infections and results in the imperative search of novel antibacterial approaches. In this regard, EO-based compounds have been pointed out as a suitable strategy due to their bactericidal properties together with their inability to generate antimicrobial resistances [12-15]. Previous studies have highlighted these promising attributes [17-22] though their complex composition is tightly joined to different factors (i.e., seasonal variation, age), which means variability in their bactericidal effects. Thus, in order to delve into EOs antibacterial activity, it is necessary to focus on the study of their main components.

Our work focuses on the bactericidal effects and the mechanisms of action of purified EO-present molecules (CRV, CIN, THY), circumventing their intrinsic variability associated to their plant extraction, against Gram positive (S. aureus) and Gram negative (E. coli) bacteria in order to elucidate their own ability to kill bacteria. MIC and MBC studies (Table 1 and Figure S1) pointed to THY, CRV, CIN and eugenol as the most effective studied molecules against E. coli and S. aureus showing the lowest concentrations to inhibit or hamper planktonic bacteria growth. The bactericidal mechanism of the most effective EO-derived molecules (CRV, THY, CIN) was assessed by SEM, flow cytometry and confocal microscopy after treatment of E. coli and S. aureus planktonic cultures at MIC and MBC concentrations for $24 \mathrm{~h}$ (Figures 1-3, Figures S2 and S3). These methodologies pointed to membrane disruption as the bactericidal mechanism exerted by these molecules. It is known that phenols, terpenes and aldehydes antibacterial effect is due to their action against the cell cytoplasmic membrane [42]. It has been reported that CRV and THY disturb the membrane integrity, increasing the membrane permeability and causing a leakage of protons and potassium finally leading to the loss of membrane potential [43]. Di Pascua et al. [42] suggested that the presence of the hydroxyl group in CAR and THY is related to the inactivation of the microbial enzymes. This group would interact with the cell membrane causing leakage of cellular components, a change in fatty acids and phospholipids, and an impairment of the energy metabolism influencing genetic material synthesis. However, some authors have pointed out to different bactericidal mechanisms of action for both compounds due to the different location of the hydroxyl group in their structure affecting cell membrane permeability [44], while others agree with our results, showing similar effects for both compounds on bacterial membrane structure [45]. It is important to point out that the bactericidal action cannot be related only to the $\mathrm{OH}$ group since eugenol having also a hydroxyl group exhibited lower bactericidal effect (Table 1). According to the literature, the antibacterial mechanism of CIN is not clear. On one hand, its antimicrobial action was attributed to the inhibition of the amino acid decarboxylase activity to bind proteins and no 
disintegration of the membrane was observed [24]. However, Nazzaro et al. [42] sustained that like CRV, CIN inhibits the generation of adenosine triphosphate from dextrose and disrupts the cell membrane. In addition, the hydrophobicity of the components present in EOs enables their accumulation in cell membranes disturbing their structures and causing an increase in the permeability allowing intracellular constituents leakage [43]. Our studies would indicate similar trends in MIC and MBC values for CRV, THY, and CIN, as well as the disruption of the bacterial surface as target for their activity by three different experimental techniques analyzed.

On the other hand, synergism between EO active molecules has been shown as more efficient as bactericidal agents. For instance, polyethylene films containing a mixture of CRV and THY entrapped within halloysite nanotubes exhibited superior antimicrobial activity against $E$. coli than films containing the individual compounds alone [44]. The combination of CIN and CRV showed better bactericidal effect compared with the components alone against food-borne bacteria [24]. Zhou et al. [26] reported that CIN had a synergistic effect when combined with THY or CRV against Salmonella typhimurium. However, in our case, FICI data obtained against S. aureus (Table 2 and Figure S4) pointed to CRV-THY as the most efficient combination displaying an additive effect, while CIN did not exert any synergism. The synergistic mechanism between CIN with CRV or with THY was proposed to be caused by the increase in the membrane permeability that enables CIN to be transported into the cell [24]. But according to the treated bacteria SEM micrographs (Figures 1 and 2), flow cytometry histograms (Figure S2) and confocal microscopy images (Figure 3 and Figure S3), the effect of the three compounds against E. coli is mainly outer membrane disintegration and the morphology of treated $S$. aureus was similar for the three active compounds. THY and CRV were previously found to give an additive antimicrobial effect on S. aureus [25], which is in accordance with its similar chemical structure (Table 1 ).

$S$. aureus is involved in a wide range of infections that are difficult to treat because, beside the frequent occurrence of antimicrobial-resistant strains, S. aureus often resides within biofilms at the infection site [45]. Biofilms are communities of microorganisms living at an interphase where they attach to each other through the extracellular polymeric substance also known as the biofilm matrix composed of extracellular DNA, proteins, and polysaccharides. Due to the protection of this matrix, bacteria show up to 1000 times greater tolerance to antibiotics and biocides than their planktonic counterparts [46]. Because of this, it is important to find compounds that interfere with the early steps of biofilm formation and slow down its formation rate. As expected, concentrations of the active molecules higher than MIC and even MBC values obtained for planktonic bacteria are needed for biofilm elimination. Our study shows that concentrations higher than $1 \mathrm{mg} / \mathrm{mL}$ of any of the compounds tested would be necessary for the total elimination of preformed biofilms. Again, the concentrations needed to retard biofilm growth and development were higher than the MIC values retrieved for planktonic bacteria (Table 1), but they were in the same range than those reported in the literature [32].

Regarding the use of these EO-present molecules against bactericidal infections, i.e., chronic wounds, the evaluation of their cytocompatibility in human cell cultures is advisable. Our study showed subcytotoxic concentrations between 0.015 and $0.090 \mathrm{mg} / \mathrm{mL}$, pointing to CIN as the most cytotoxic molecule assayed in human dermal fibroblasts, keratinocytes, and macrophages. However, the widely used antiseptic chlorhexidine was found more cytotoxic than the EO-based compounds, displaying a subcytotoxic concentration of $0.004 \mathrm{mg} / \mathrm{mL}$. Previous studies have also evaluated the toxicity of different compounds present in EOs on different human cell types, such as fibroblasts [47], intestinal cells [48] or different tumor cell lines [49,50]. Their results show subcytotoxic concentrations for CRV and THY in the same range as ours $(\sim 500 \mu \mathrm{M})$ [48] or higher $(50 \%$ viability at $\sim 5 \mu \mathrm{g} / \mathrm{mL})$ [47] and also very similar for CIN $(\sim 10 \mu \mathrm{g} / \mathrm{mL})$ [50] pointing to apoptosis and membrane damage as key cytotoxic mechanisms. Even though the studied molecules showed cytotoxic activity at doses above $0.06-0.09 \mathrm{mg} / \mathrm{mL}$, it is important to point out that during the regenerative process in an infected wound the antimicrobial compound at those doses would eradicate both bacteria and 
eukaryotic cells, but while bacteria are removed from the injury, eukaryotic cells are continuously arriving to the wound to participate in the regenerative process [27]. Hence, only a small fraction of eukaryotic cells would be damaged.

Finally, the present work has shown the bactericidal effects and mechanisms of promising antibacterial purified EO-based compounds (CRV, THY, CIN), avoiding the variability of plant extracted compounds, for their incorporation to different clinical treatments, i.e., wound dressings for chronic wounds. Their efficiency against both planktonic and biofilm bacteria highlights their potential to be included in bactericidal approaches in order to develop novel strategies against antibiotic and antiseptic resistance.

\section{Materials and Methods}

\subsection{Materials}

Carvacrol (CRV), cinnamaldehyde (CIN), thymol (THY), Squalene, Rosmarinic acid, $\beta$-Caryophyllene, Calcofluor White Stain, phorbol 12-myristate 13-acetate (PMA), and Tween ${ }^{\circledR} 80$ were purchased from Sigma-Aldrich (St. Louis, MO, USA), while Eugenol was supplied by Acros Organics (Gell, Belgium). Tryptone soy broth (TSB) and agar (TSA) were obtained from Conda-Pronadisa (Madrid, Spain) and S. aureus (ATCC 25923) from Ielab (Alicante, Spain). Regarding cell lines, human dermal fibroblasts were purchased from Lonza (Bornem, Belgium), and THP1 human monocytes (ATCC TIB-202) from LGC Standards (Barcelona, Spain), while human keratinocytes were kindly gifted by Dr Pilar Martín-Duque. High-glucose DMEM (DMEM w/stable glutamine), RPMI $1640 \mathrm{w} /$ stable glutamine, and antibiotic-antimycotic $(60 \mu \mathrm{g} / \mathrm{mL}$ penicillin, $100 \mu \mathrm{g} / \mathrm{mL}$ streptomycin and $0.25 \mu \mathrm{g} / \mathrm{mL}$ amphotericin B) were supplied by Biowest (CEDEX, France). Cell culture reagents, such as fetal bovine serum (FBS), HEPES, nonessential amino acids, 2-mercaptoethanol $50 \mathrm{mM}$ and sodium pyruvate $100 \mathrm{mM}$, were obtained from Gibco (Manchester, UK), and the Blue Cell Viability assay from Abnova (Aachen, Germany).

\subsection{Bacteria Culture}

A Gram-negative model E. coli S17 strain was used, which was kindly donated by Dr. Jose Antonio Ainsa, exerting resistance to streptomycin as it is also widely used for transformation purposes [51]. S. aureus ATCC 25923, well-known as not a resistant strain and used in susceptibility tests [52,53], was evaluated as a Gram-positive model. Both strains were initially grown overnight in TSB at $37^{\circ} \mathrm{C}$ under shaking (150 rpm) obtaining, in the stationary growth phase, $10^{8}-10^{9} \mathrm{CFU} / \mathrm{mL}$. TSA was used for seeding bacteria in an incubator at $37^{\circ} \mathrm{C}$ (Memmert, Schwabach, Germany) in order to calculate the bacteria growth $(\mathrm{CFU} / \mathrm{mL})$ after treatment with the EO-contained molecules.

\subsection{Biofilm Formation}

S. aureus was grown overnight in TSB until stationary growth phase was reached. At this point, bacteria were adjusted to $10^{7} \mathrm{CFU} / \mathrm{mL}$ and added to a MW96 microplate and incubated at $37^{\circ} \mathrm{C}$ for $16 \mathrm{~h}$ without shaking. After incubation, culture medium was discarded and biofilms were washed twice with PBS. In order to determine biofilm formation, Calcofluor White Stain $(50 \mu \mathrm{L})$ was added to each well and incubated $1 \mathrm{~min}$ in the dark at room temperature. After incubation, the stain was removed and biofilms were washed twice with PBS. Samples were air-dried in the dark to be further visualized in an inverted fluorescence microscope (Olympus IX81).

To be analyzed by SEM, biofilms were grown on sterile glass slides incubated in a S. aureus planktonic suspension $\left(10^{7} \mathrm{CFU} / \mathrm{mL}\right)$ at $37^{\circ} \mathrm{C}$ for $16 \mathrm{~h}$ without shaking. Then, biofilms were washed twice with PBS $(0.1 \mathrm{M})$ and fixed in $2.5 \%$ glutaraldehyde for $3 \mathrm{~h}$. Samples were dehydrated through a series of ethanol solutions (30, 50, 70, 80, 90 and 100\%; 15 min, twice). Finally, samples were air-dried at room temperature and coated with $\mathrm{Pt}$ to allow electronic observation. SEM images were acquired in the energy range of 10-15 keV in an SEM Inspect ${ }^{\mathrm{TM}}$ F50 (FEI Co., Hillsboro, OR, USA). 


\subsection{Antibacterial Activity}

\subsubsection{MIC and MBC Determination}

Inhibitory and bactericidal concentrations of active EO molecules were tested in two bacteria cultures, E. coli and S. aureus, following the broth microdilution method. Liquid growth medium containing an inoculum of $10^{5} \mathrm{CFU} / \mathrm{mL}$ and serial concentrations of the EO compounds $(0.1-4 \mathrm{mg} / \mathrm{mL})$ were used. EO compounds were solubilized in culture medium by adding Tween ${ }^{\circledR} 80(1.5-2 \%$ v/v) prior to their serial dilution. Once bacteria suspension was in stationary growth $\left(10^{8}-10^{9} \mathrm{CFU} / \mathrm{mL}\right)$, it was further diluted to $\sim 10^{5} \mathrm{CFU} / \mathrm{mL}$ and added to different concentrations $(0.01-4 \mathrm{mg} / \mathrm{mL})$ of the antimicrobial agents. Then, samples were incubated for $24 \mathrm{~h}$ at $37^{\circ} \mathrm{C}$ under shaking (150 rpm). After incubation, bacterial suspensions were diluted in PBS and spot-plated on TSA plates to count colonies after incubation at $37^{\circ} \mathrm{C}$ for $24 \mathrm{~h}$. Positive control (untreated bacteria) and negative control (chlorhexidine treated bacteria) samples were also tested.

\subsubsection{SEM}

Bacteria morphology before and after treatment with EO molecules was analyzed by SEM as we previously reported [54]. Briefly, logarithmic growth phase E. coli and S. aureus bacteria cultures $\left(\sim 10^{5} \mathrm{CFU} / \mathrm{mL}\right)$ were treated with the selected EO compounds at MIC and MBC values and incubated overnight at $37^{\circ} \mathrm{C}$. Following incubation, samples were spin-dried at $600 \mathrm{~g}$ and washed twice in PBS (0.1 M). Bacteria were fixed in 2.5\% glutaraldehyde for $90 \mathrm{~min}$ and subsequently filtered and dehydrated in ethanol solutions series (30, 50, 70, 80, 90, and 100\%; twice for 15 min). Finally, samples were air-dried at room temperature and covered with Pt. SEM micrographs were acquired in a SEM Inspect F50 equipment (FEI Co., LMA-INA, Zaragoza, Spain).

\subsubsection{Flow Cytometry}

In order to study the bactericidal mechanism of the different molecules present in EOs, E. coli and S. aureus bacteria samples $\left(10^{7} \mathrm{CFU} / \mathrm{mL}\right)$ were centrifuged at $4400 \times g$ for $10 \mathrm{~min}$ and resuspended in the different compound solutions at MIC and MBC concentrations following the protocols previously described [39,54]. Control groups (not treated and chlorhexidine treated bacteria) were also analyzed. All samples were incubated overnight at $37^{\circ} \mathrm{C}$. After propidium iodide $(25 \mu \mathrm{g} / \mathrm{mL}$; Sigma-Aldrich, Munich, Germany) addition, samples were analyzed by flow cytometry in Gallios equipment (Beckman Coulter Company, Cell Separation and Cytometry Unit, CIBA, IIS Aragon, Zaragoza, Spain).

\subsubsection{Confocal Microscopy}

The Live/Dead ${ }^{\circledR}$ BacLight ${ }^{\mathrm{TM}}$ bacterial viability kit (Molecular Probes, Fisher Scientific, Hampton, USA) was used to detect bacteria membrane damage. The methodology is based on the double-staining by SYTO9 and propidium iodide as indicated by the manufacturer. Bacteria samples incubated at $24 \mathrm{~h}\left(10^{7} \mathrm{CFU} / \mathrm{mL}\right)$ and treated with the selected EO compounds at MIC were washed in sterile saline solution and further put in contact with the dye mixture for $15 \mathrm{~min}$ in the dark at room temperature. Samples were then mounted on slides and visualized by confocal microscopy (Leica TCS SP2 Laser Scanning Confocal Microscope, Microscopy Unit, CIBA, IIS Aragon, Zaragoza, Spain). Control samples were also tested as described above.

\subsubsection{Synergy Studies}

The Broth Dilution Checkerboard test was used to evaluate the interaction among the three most promising bactericidal EO molecules determined by the MIC and MBC studies against $S$. aureus as previously reported [55]. In brief, a solution containing four times the MBC of each compound was prepared. By using a MW96 plate and fresh medium, compound A was diluted two-fold in vertical orientation and compound $\mathrm{B}$ was diluted two-fold in horizontal direction. Then, a bacterial suspension $\left(10^{6} \mathrm{CFU} / \mathrm{mL}, 100 \mu \mathrm{L}\right)$ was added and the plate was incubated overnight at $37^{\circ} \mathrm{C}$. After incubation, 
bacteria growth was determined by the resazurin assay. The Fractional Inhibitory Concentration Index (FICI) of the combination of compounds A and B was calculated according to the following equation:

$$
F I C I=\mathrm{FIC}_{\mathrm{A}}+\mathrm{FIC}_{\mathrm{B}}
$$

where

$$
\mathrm{FIC}_{\mathrm{A}}=\frac{\text { MICA in presence of } B}{\text { MIC of } A} \text { and } \mathrm{FIC}_{\mathrm{B}}=\frac{\text { MICB in presence of } A}{\text { MIC of } B}
$$

$F I C I$ results were classified as synergy $(F I C I<0.5)$, addition $(0.5 \leq F I C I \leq 1)$, indifference $(1<F I C I \leq 4)$ or antagonism $(F I C I>4)$, as previously described [56].

\subsubsection{Biofilm Disruption}

The effects of EO molecules $(0.25-1 \mathrm{mg} / \mathrm{mL})$ to prevent the formation of biofilm and to disrupt an already formed S. aureus biofilm were studied. EO compounds were added to preformed biofilms and samples were incubated for $24 \mathrm{~h}$ at $37^{\circ} \mathrm{C}$ without shaking. After incubation, biofilms were disrupted by sonication ( $15 \mathrm{~min}, 200 \mathrm{~W}$; Ultrasons, JP Selecta, Barcelona, Spain). Samples were then diluted and seeded onto agar plates to count the viable colonies grown after $24 \mathrm{~h}$ of incubation at $37^{\circ} \mathrm{C}$.

To study the effects of the compounds present in the EOs on biofilm formation, those were added to bacterial suspensions $\left(10^{7} \mathrm{CFU} / \mathrm{mL}\right)$ in a MW96 microplate and incubated for $16 \mathrm{~h}$ at $37^{\circ} \mathrm{C}$ without shaking. After incubation, planktonic cells were removed by washing them twice with PBS. Biofilm samples were then sonicated as described above and serially diluted to be further plated on agar. Viable bacteria $(\mathrm{CFU} / \mathrm{mL})$ were counted after $24 \mathrm{~h}$ of incubation at $37^{\circ} \mathrm{C}$.

\subsubsection{Cell Culture and Cytotoxicity Assays}

Human dermal fibroblasts, human epidermal keratinocytes (HaCaT), and THP1 human monocytes were used to evaluate the cytotoxic effects of EO-based compounds.

Fibroblasts and $\mathrm{HaCaT}$ were routinely grown in high-glucose DMEM supplemented with $10 \%$ FBS and antibiotic-antimycotic. Monocytes were cultured in RPMI 1640 supplemented with $10 \%$ FBS, $1 \%$ HEPES, 1\% nonessential amino acids, $0.1 \%$ 2-mercaptoethanol $50 \mathrm{mM}, 1 \%$ sodium pyruvate $100 \mathrm{mM}$, and antibiotic-antimycotic. Macrophages were obtained by the in vitro differentiation of monocytes by adding $1 \mu \mathrm{M}$ PMA to the cell culture. All cell types were grown in a humidified atmosphere at $37^{\circ} \mathrm{C}$ and $5 \% \mathrm{CO}_{2}$.

The cytotoxicity was determined by measuring cell metabolism through the Blue Cell Viability assay. Cells were seeded on MW96 microplates and incubated with the tested molecules $(0.004-0.125 \mathrm{mg} / \mathrm{mL})$ for $24 \mathrm{~h}$. Control samples (not treated and chlorhexidine treated) were also analyzed. Then, the reagent was added $(10 \%)$ and cells were incubated for $4 \mathrm{~h}$ at $37^{\circ} \mathrm{C}$. The reduction of the dye by metabolically active cells was monitored in a microplate reader (Multimode Synergy HT Microplate Reader; Biotek, Winooski, WI, USA) at 535/590 nm ex/em. Cell viability was determined by interpolation of the emission data obtained from the treated samples and the control samples (not treated cells, 100\% viability).

\subsubsection{Statistical Analysis}

Results are reported as mean \pm SD. The normal distribution of the variables was analyzed by the Shapiro-Wilk test followed by the U-Mann-Whitney or Student test (StataSE 12 statistical software, StataCorp LP, Texas, TX, USA). Statistically significant differences among groups were considered when $p \leq 0.05$.

\section{Conclusions}

Compounds present in EOs including CRV, CIN, and THY exhibit the highest in vitro antimicrobial activities against E. coli and S. aureus of all the antimicrobials tested. THY showed the lowest MBC values $(0.3 \mathrm{mg} / \mathrm{mL})$ among all of the compounds tested and was the most effective 
bactericide against the Gram-negative and Gram-positive strains evaluated. According to SEM images, flow cytometry and confocal microscopy bacteria membrane disruption is the bactericidal mechanism attributable to CRV, CIN, and THY. There was no antagonism between the tested active compounds, but no synergism was found either; only the CRV-THY combination showed an additive effect. The presence of those compounds at concentrations above $0.5 \mathrm{mg} / \mathrm{mL}$ hinders $S$. aureus biofilm formation and also partially eliminates preformed biofilms. The subcytotoxic values of the tested EO compounds $(0.015-0.090 \mathrm{mg} / \mathrm{mL})$ are lower than MICs and MBCs for bacteria but much higher than chlorhexidine doses $(0.004 \mathrm{mg} / \mathrm{mL})$. The presence of those antibacterial compounds at MBC concentrations would be only three orders of magnitude higher than the subcytotoxic dose in the worst-case scenario.

Supplementary Materials: The following are available online at http:/ /www.mdpi.com/1420-3049/23/6/1399/ s1, Figure S1: Bacteria growth (CFU/mL) for E. coli and S. aureus at MIC values for carvacrol, cinnamaldehyde and thymol active compounds, Figure S2: Flow cytometry histograms at MBC on S. aureus and E. coli, Figure S3: S. aureus and E. coli confocal images after treatment with carvacrol, cinnamaldehyde and thymol, Figure S4: Synergistic effects of the EO molecules assayed against $S$. aureus.

Author Contributions: H.E.-C. and S.G.-S.: performing experiments and preparation of the figures; S.I., M.A. and G.M.: designing of the experiments and preparing the manuscript. S.I. and M.A.: Principal investigators and heads of the project. All authors reviewed the manuscript.

Funding: This research was funded by the Spanish Ministry of Economy and Competitiveness (grant number CTQ2014-52384-R). The authors also acknowledge the financial support of the ERC Consolidator Grant program (ERC-2013-CoG-614715). CIBER-BBN is an initiative funded by the VI National R\&D\&i Plan 2008-2011, Iniciativa Ingenio 2010, Consolider Program, CIBER Actions and financed by the Instituto de Salud Carlos III (Spain) with assistance from the European Regional Development Fund.

Acknowledgments: The authors acknowledge the LMA-INA and Cell Culture, Animal Care, Pathological Anatomy and Medical Imaging and Phenotyping Core Units from University of Zaragoza and IACS/IIS Aragon for their instruments and expertise.

Conflicts of Interest: The authors declare no conflict of interest.

\section{References}

1. Langeveld, W.T.; Veldhuizen, E.J.A.; Burt, S.A. Synergy between essential oil components and antibiotics: A review. Crit. Rev. Microbiol. 2014, 40, 76-94. [CrossRef] [PubMed]

2. Hiltunen, T.; Virta, M.; Laine, A.-L. Antibiotic resistance in the wild: An eco-evolutionary perspective. Philos. Trans. R. Soc. B Biol. Sci. 2017, 372, 20160039. [CrossRef] [PubMed]

3. Aperce, C.C.; Amachawadi, R.; Van Bibber-Krueger, C.L.; Nagaraja, T.G.; Scott, H.M.; Vinasco-Torre, J.; Drouillard, J.S. Effects of Menthol Supplementation in Feedlot Cattle Diets on the Fecal Prevalence of Antimicrobial-Resistant Escherichia coli. PLoS ONE 2016, 11, e0168983. [CrossRef] [PubMed]

4. Home IAMR Review. Available online: https://amr-review.org/ (accessed on 20 May 2018).

5. Centers for Disease Control and Prevention. Available online: https:/ / www.cdc.gov/ (accessed on 20 May 2018).

6. Chambers, H.F.; Deleo, F.R. Waves of resistance: Staphylococcus aureus in the antibiotic era. Nat. Rev. Microbiol. 2009, 7, 629-641. [CrossRef] [PubMed]

7. Laxminarayan, R.; Duse, A.; Wattal, C.; Zaidi, A.K.M.; Wertheim, H.F.L.; Sumpradit, N.; Vlieghe, E.; Hara, G.L.; Gould, I.M.; Goossens, H.; et al. Antibiotic resistance-the need for global solutions. Lancet Infect. Dis. 2013, 13, 1057-1098. [CrossRef]

8. Bush, K.; Courvalin, P.; Dantas, G.; Davies, J.; Eisenstein, B.; Huovinen, P.; Jacoby, G.A.; Kishony, R.; Kreiswirth, B.N.; Kutter, E.; et al. Tackling antibiotic resistance. Nat. Rev. Microbiol. 2011, 9, 894-896. [CrossRef] [PubMed]

9. Scandorieiro, S.; de Camargo, L.C.; Lancheros, C.A.C.; Yamada-Ogatta, S.F.; Nakamura, C.V.; de Oliveira, A.G.; Andrade, C.G.T.J.; Duran, N.; Nakazato, G.; Kobayashi, R.K.T. Synergistic and Additive Effect of Oregano Essential Oil and Biological Silver Nanoparticles against Multidrug-Resistant Bacterial Strains. Front. Microbiol. 2016, 7, 760. [CrossRef] [PubMed]

10. Billing, J.; Sherman, P.W. Antimicrobial functions of spices: Why some like it hot. Q. Rev. Biol. 1998, 73, 3-49. [CrossRef] [PubMed] 
11. Lu, Z.; Chen, Y.; Chen, W.; Liu, H.; Song, Q.; Hu, X.; Zou, Z.; Liu, Z.; Duo, L.; Yang, J.; et al. Characteristics of qacA/B-positive Staphylococcus aureus isolated from patients and a hospital environment in China. J. Antimicrob. Chemother. 2015, 70, 653-657. [CrossRef] [PubMed]

12. Apolónio, J.; Faleiro, M.L.; Miguel, M.G.; Neto, L. No induction of antimicrobial resistance in Staphylococcus aureus and Listeria monocytogenes during continuous exposure to eugenol and citral. FEMS Microbiol. Lett. 2014, 354, 92-101. [CrossRef] [PubMed]

13. Becerril, R.; Nerín, C.; Gómez-Lus, R. Evaluation of bacterial resistance to essential oils and antibiotics after exposure to oregano and cinnamon essential oils. Foodborne Pathog. Dis. 2012, 9, 699-705. [CrossRef] [PubMed]

14. Magi, G.; Marini, E.; Facinelli, B. Antimicrobial activity of essential oils and carvacrol, and synergy of carvacrol and erythromycin, against clinical, erythromycin-resistant Group A Streptococci. Front. Microbiol. 2015, 6, 165. [CrossRef] [PubMed]

15. Walsh, S.E.; Maillard, J.-Y.; Russell, A.D.; Catrenich, C.E.; Charbonneau, D.L.; Bartolo, R.G. Development of bacterial resistance to several biocides and effects on antibiotic susceptibility. J. Hosp. Infect. 2003, 55, 98-107. [CrossRef]

16. Bilia, A.R.; Guccione, C.; Isacchi, B.; Righeschi, C.; Firenzuoli, F.; Bergonzi, M.C. Essential oils loaded in nanosystems: A developing strategy for a successful therapeutic approach. Evid. Based Complement. Altern. Med. 2014, 2014, 651593. [CrossRef] [PubMed]

17. Hui, X.; Yan, G.; Tian, F.-L.; Li, H.; Gao, W.-Y. Antimicrobial mechanism of the major active essential oil compounds and their structure-activity relationship. Med. Chem. Res. 2017, 26, 442-449. [CrossRef]

18. Nostro, A.; Blanco, A.R.; Cannatelli, M.A.; Enea, V.; Flamini, G.; Morelli, I.; Sudano Roccaro, A.; Alonzo, V. Susceptibility of methicillin-resistant staphylococci to oregano essential oil, carvacrol and thymol. FEMS Microbiol. Lett. 2004, 230, 191-195. [CrossRef]

19. Cho, Y.; Lee, H.-J. Antibacterial effects of carvacrol against Staphylococcus aureus and Escherichia coli O157:H7. J. Biomed. Res. 2014, 15, 117-122. [CrossRef]

20. Wang, L.-H.; Wang, M.-S.; Zeng, X.-A.; Zhang, Z.-H.; Gong, D.-M.; Huang, Y.-B. Membrane Destruction and DNA Binding of Staphylococcus aureus Cells Induced by Carvacrol and Its Combined Effect with a Pulsed Electric Field. J. Agric. Food Chem. 2016, 64, 6355-6363. [CrossRef] [PubMed]

21. Silva da Luz, I.; Gomes Neto, N.J.; Tavares, A.G.; Nunes, P.C.; Magnani, M.; de Souza, E.L. Lack of induction of direct protection or cross-protection in Staphylococcus aureus by sublethal concentrations of Origanum vulgare $\mathrm{L}$. essential oil and carvacrol in a meat-based medium. Arch. Microbiol. 2013, 195, 587-593. [CrossRef] [PubMed]

22. Rúa, J.; Fernández-Álvarez, L.; de Castro, C.; del Valle, P.; de Arriaga, D.; García-Armesto, M.R. Antibacterial Activity Against Foodborne Staphylococcus aureus and Antioxidant Capacity of Various Pure Phenolic Compounds. Foodborne Pathog. Dis. 2011, 8, 149-157. [CrossRef] [PubMed]

23. Gavaric, N.; Mozina, S.S.; Kladar, N.; Bozin, B. Chemical Profile, Antioxidant and Antibacterial Activity of Thyme and Oregano Essential Oils, Thymol and Carvacrol and Their Possible Synergism. J. Essent. Oil Bear. Plants 2015, 18, 1013-1021. [CrossRef]

24. Ye, H.; Shen, S.; Xu, J.; Lin, S.; Yuan, Y.; Jones, G.S. Synergistic interactions of cinnamaldehyde in combination with carvacrol against food-borne bacteria. Food Control 2013, 34, 619-623. [CrossRef]

25. Lambert, R.J.; Skandamis, P.N.; Coote, P.J.; Nychas, G.J. A study of the minimum inhibitory concentration and mode of action of oregano essential oil, thymol and carvacrol. J. Appl. Microbiol. 2001, 91, 453-462. [CrossRef] [PubMed]

26. Zhou, F.; Ji, B.; Zhang, H.; Jiang, H.; Yang, Z.; Li, J.; Li, J.; Yan, W. The antibacterial effect of cinnamaldehyde, thymol, carvacrol and their combinations against the foodborne pathogen Salmonella Thypimurium. J. Food Saf. 2007, 27, 124-133. [CrossRef]

27. Andreu, V.; Mendoza, G.; Arruebo, M.; Irusta, S. Smart Dressings Based on Nanostructured Fibers Containing Natural Origin Antimicrobial, Anti-Inflammatory, and Regenerative Compounds. Materials 2015, 8, 5154-5193. [CrossRef] [PubMed]

28. Fratini, F.; Mancini, S.; Turchi, B.; Friscia, E.; Pistelli, L.; Giusti, G.; Cerri, D. A novel interpretation of the Fractional Inhibitory Concentration Index: The case Origanum vulgare L. and Leptospermum scoparium J. R. et G. Forst essential oils against Staphylococcus aureus strains. Microbiol. Res. 2017, 195, 11-17. [CrossRef] [PubMed] 
29. De Sousa, N.T.A.; Gomes, R.C.; Santos, M.F.; Brandino, H.E.; Martinez, R.; de Jesus Guirro, R.R. Red and infrared laser therapy inhibits in vitro growth of major bacterial species that commonly colonize skin ulcers. Lasers Med. Sci. 2016, 31, 549-556. [CrossRef] [PubMed]

30. Duncan, B.; Li, X.; Landis, R.F.; Kim, S.T.; Gupta, A.; Wang, L.-S.; Ramanathan, R.; Tang, R.; Boerth, J.A.; Rotello, V.M. Nanoparticle-Stabilized Capsules for the Treatment of Bacterial Biofilms. ACS Nano 2015, 9, 7775-7782. [CrossRef] [PubMed]

31. Ciandrini, E.; Campana, R.; Federici, S.; Manti, A.; Battistelli, M.; Falcieri, E.; Papa, S.; Baffone, W. In vitro activity of Carvacrol against titanium-adherent oral biofilms and planktonic cultures. Clin. Oral Investig. 2014, 18, 2001-2013. [CrossRef] [PubMed]

32. Kifer, D.; Mužinić, V.; Klarić, M.Š. Antimicrobial potency of single and combined mupirocin and monoterpenes, thymol, menthol and 1,8-cineole against Staphylococcus aureus planktonic and biofilm growth. J. Antibiot. 2016, 69, 689-696. [CrossRef] [PubMed]

33. Moghimi, R.; Aliahmadi, A.; Rafati, H. Ultrasonic nanoemulsification of food grade trans-cinnamaldehyde: 1,8-Cineol and investigation of the mechanism of antibacterial activity. Ultrason. Sonochem. 2017, 35, 415-421. [CrossRef] [PubMed]

34. Devi, K.P.; Sakthivel, R.; Nisha, S.A.; Suganthy, N.; Pandian, S.K. Eugenol alters the integrity of cell membrane and acts against the nosocomial pathogen Proteus mirabilis. Arch. Pharm. Res. 2013, 36, 282-292. [CrossRef] [PubMed]

35. Sabulal, B.; Dan, M.; Kurup, R.; Pradeep, N.S.; Valsamma, R.K.; George, V. Caryophyllene-rich rhizome oil of Zingiber nimmonii from South India: Chemical characterization and antimicrobial activity. Phytochemistry 2006, 67, 2469-2473. [CrossRef] [PubMed]

36. Slobodníková, L.; Fialová, S.; Hupková, H.; Grancai, D. Rosmarinic acid interaction with planktonic and biofilm Staphylococcus aureus. Nat. Prod. Commun. 2013, 8, 1747-1750. [PubMed]

37. Liang, Y.; Yuxia, Z.; Yabo, J.; Yajie, H.; Jianyu, W.; Zepeng, C.; Dingxin, J. ESR Study on Scavenging Effect of Squalene on Free Radicals in Mainstream Cigarette Smoke. Appl. Magn. Reson. 2017, 48, 201-212. [CrossRef]

38. Kuyyakanond, T; Quesnel, L.B. The mechanism of action of chlorhexidine. FEMS Microbiol. Lett. 1992, 100, $211-215$. [CrossRef] [PubMed]

39. Gant, V.A.; Warnes, G.; Phillips, I.; Savidge, G.F. The application of flow cytometry to the study of bacterial responses to antibiotics. J. Med. Microbiol. 1993, 39, 147-154. [CrossRef] [PubMed]

40. Xiao, L.; Miwa, N. Hydrogen-rich water achieves cytoprotection from oxidative stress injury in human gingival fibroblasts in culture or 3D-tissue equivalents, and wound-healing promotion, together with ROS-scavenging and relief from glutathione diminishment. Hum. Cell 2017, 30, 72-87. [CrossRef] [PubMed]

41. ISO 10993-5:2009-Biological Evaluation of Medical Devices-Part 5: Tests for In Vitro Cytotoxicity. Available online: https:/ / www.iso.org/standard/36406.html (accessed on 22 May 2018).

42. Nazzaro, F.; Fratianni, F.; De Martino, L.; Coppola, R.; De Feo, V. Effect of essential oils on pathogenic bacteria. Pharmaceuticals 2013, 6, 1451-1474. [CrossRef] [PubMed]

43. Lv, F.; Liang, H.; Yuan, Q.; Li, C. In vitro antimicrobial effects and mechanism of action of selected plant essential oil combinations against four food-related microorganisms. Food Res. Int. 2011, 44, 3057-3064. [CrossRef]

44. Krepker, M.; Shemesh, R.; Danin Poleg, Y.; Kashi, Y.; Vaxman, A.; Segal, E. Active food packaging films with synergistic antimicrobial activity. Food Control 2017, 76, 117-126. [CrossRef]

45. Van den Driessche, F.; Brackman, G.; Swimberghe, R.; Rigole, P.; Coenye, T. Screening a repurposing library for potentiators of antibiotics against Staphylococcus aureus biofilms. Int. J. Antimicrob. Agents 2017, 49, 315-320. [CrossRef] [PubMed]

46. Krogsgård Nielsen, C.; Kjems, J.; Mygind, T.; Snabe, T.; Schwarz, K.; Serfert, Y.; Meyer, R.L. Antimicrobial effect of emulsion-encapsulated isoeugenol against biofilms of food pathogens and spoilage bacteria. Int. J. Food Microbiol. 2017, 242, 7-12. [CrossRef] [PubMed]

47. Melo, J.O.; Fachin, A.L.; Rizo, W.F.; Jesus, H.C.R.; Arrigoni-Blank, M.F.; Alves, P.B.; Marins, M.A.; França, S.C.; Blank, A.F. Cytotoxic effects of essential oils from three Lippia gracilis Schauer genotypes on HeLa, B16, and MCF-7 cells and normal human fibroblasts. Genet. Mol. Res. 2014, 13, 2691-2697. [CrossRef] [PubMed]

48. Llana-Ruiz-Cabello, M.; Gutiérrez-Praena, D.; Pichardo, S.; Moreno, F.J.; Bermúdez, J.M.; Aucejo, S.; Cameán, A.M. Cytotoxicity and morphological effects induced by carvacrol and thymol on the human cell line Caco-2. Food Chem. Toxicol. 2014, 64, 281-290. [CrossRef] [PubMed] 
49. Günes-Bayir, A.; Kiziltan, H.S.; Kocyigit, A.; Güler, E.M.; Karataş, E.; Toprak, A. Effects of natural phenolic compound carvacrol on the human gastric adenocarcinoma (AGS) cells in vitro. Anti-Cancer Drugs 2017, 28, 522-530. [CrossRef] [PubMed]

50. Yu, C.; Liu, S.-L.; Qi, M.-H.; Zou, X. Cinnamaldehyde/chemotherapeutic agents interaction and drug-metabolizing genes in colorectal cancer. Mol. Med. Rep. 2014, 9, 669-676. [CrossRef] [PubMed]

51. Strand, T.A.; Lale, R.; Degnes, K.F.; Lando, M.; Valla, S. A new and improved host-independent plasmid system for RK2-based conjugal transfer. PLoS ONE 2014, 9, e90372. [CrossRef] [PubMed]

52. Ribeiro, J.; Vieira, F.D.; King, T.; D'Arezzo, J.B.; Boyce, J.M. Misclassification of susceptible strains of Staphylococcus aureus as methicillin-resistant $S$. aureus By a rapid automated susceptibility testing system. J. Clin. Microbiol. 1999, 37, 1619-1620. [PubMed]

53. Treangen, T.J.; Maybank, R.A.; Enke, S.; Friss, M.B.; Diviak, L.F.; Karaolis, D.K.R.; Koren, S.; Ondov, B.; Phillippy, A.M.; Bergman, N.H.; et al. Complete Genome Sequence of the Quality Control Strain Staphylococcus aureus subsp. aureus ATCC 25923. Genome Announc. 2014, 2. [CrossRef] [PubMed]

54. Mendoza, G.; Regiel-Futyra, A.; Andreu, V.; Sebastián, V.; Kyzioł, A.; Stochel, G.; Arruebo, M. Bactericidal Effect of Gold-Chitosan Nanocomposites in Coculture Models of Pathogenic Bacteria and Human Macrophages. ACS Appl. Mater. Interfaces 2017, 9, 17693-17701. [CrossRef] [PubMed]

55. Schelz, Z.; Molnar, J.; Hohmann, J. Antimicrobial and antiplasmid activities of essential oils. Fitoterapia 2006, 77, 279-285. [CrossRef] [PubMed]

56. Gutierrez, J.; Barry-Ryan, C.; Bourke, P. The antimicrobial efficacy of plant essential oil combinations and interactions with food ingredients. Int. J. Food Microbiol. 2008, 124, 91-97. [CrossRef] [PubMed]

Sample Availability: Samples of the compounds are not available from the authors.

(C) 2018 by the authors. Licensee MDPI, Basel, Switzerland. This article is an open access article distributed under the terms and conditions of the Creative Commons Attribution (CC BY) license (http://creativecommons.org/licenses/by/4.0/). 